\title{
A VAR Model Of The Relationship Between The GDP Growth And Unemployment Rates
}

Nkanta Frank Ekanem, (E-mail: fekanem@howard.edu), Howard University

\begin{abstract}
This paper concludes that the failure to realize the anticipated job growth, following the enormous fiscal injection since 2001 is mostly due to three reasons: (1) The pervasive low investors' confidence had drastically reduced the investors' propensity to invest to the extent that little or no investment could take place, even if interest rate, which had fallen to its lowest level could be allowed to fall further. (2) Many industrial sectors, still saturated with excess technological investment acquired in 1998-99, in their attempt to remain Y2K compatible, were trying to make effective use of their existing investment and hence had no justification for further investment, and this constrained their ability to expand production and create jobs. (3) The pressure to prevent corporate profits from falling increased the urge to move industrial plants overseas, especially to low wage countries.
\end{abstract}

\section{INTRODUCTION}

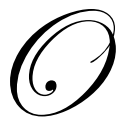

n January 15 2003, President George W. Bush gave a speech before the Economic Club of Chicago in which he laid out his plan for economic recovery. The President said in his speech that signs of economic decline were evident as early as the summer of 2000 when "the market had started on a steady decline, and the economy and job growth had begun to slow down." The President informed his audience of the continuous state of instability in the economy, in which many who wanted to work could not find a job; and the lack of confidence among many employers could not encourage them to invest and create new jobs. He also stated that a large number of Americans live in constant or increasing personal debt. In spite of these, he stated that many familiar economic indicators that drive the economy into growth were evident. These include the growing skill and efficiency of the American worker. He observed that in the preceding four quarters productivity of American workers has gone up by $5.6 \%$ which would create a platform for long term growth.

Given these problems, the President went on to announce the centerpiece of the Administration's stabilization package which is built on a series of tax reduction packages. This tax reduction proposal, when passed by Congress seeks to "put $\$ 70$ billion to work in the private economy and to encourage greater investment by individuals and small business" to speed up the pace of economic recovery and job creation. As could be expected, the President did not present comprehensive economic recovery proposals in one single speech. However, the failure of the economy to show signs of recovery several months after the launching of the recovery program, and the President's emphasis on tax reduction policy as a strategy for economic recovery calls for a search for other economic policies that may bring about a recovery both in the short and long term.

Given the productivity rate of $5.6 \%$, a national unemployment rate of $6.1 \%$, it appears that the stage is set for the economy's readiness to absorb reasonable expansionary stimulus. The federal government has apparently settled on two policy strategies: namely tax reduction, and a massive spending increase. Homeland Security related activities, arising from the September 11, 2001 bombings in New York City and Washington DC constitute the bulk of the growing trend in government spending. Many economic indicators are needed to evaluate the prospects for recovery and stability. While some of these indicators may be growth enhancing, many are not. Among those indices which do not lend themselves to growth is the pervasive decline in consumer confidence. Another is the precipitous drop in the revenue collection, and the consequent increase in the reported and projected budget deficit. 
One of the most critical decisions confronting the government is the choice of what stabilization problem to address in a way that will make the greatest impact on the economy. From every indication, although stimulating the GDP growth rate may be popular, it may however be incapable of creating jobs that the public may expect. In these circumstances, should government direct its policies towards bringing about GDP growth or job growth? Whichever of these problems government may choose to address, can the solution be found in increased spending and, or tax reduction? Although the analysis of economic instability encompasses a wide range of issues, such as prices, unemployment, GDP growth, and the domestic and external imbalance, this study will focus on the causes of, and possible solutions for three types of economic instability, namely unemployment, job growth and the GDP growth rate. These are three of the issues currently receiving wide media commentary and the public concern on economic performance. Superficially, it appears that unemployment and the GDP growth are the same things. Judging from the experience since year 2000 when the declining GDP growth in the U.S. economy has generally been associated with increasing unemployment rate, one would be inclined to agree with this line of thinking. The paper discusses some standard stabilization policies, and inquires into whether such policies have lost their ability to the first recession of the $21^{\text {st }}$ century or any others like it. The focus of the study is twofold: to test the hypothesis that the variables which explain the variability in the GDP growth are different from those, which explain the variability in unemployment rate. The second hypothesis to be tested is that the determinants of the GDP growth, job growth and unemployment have lost their predictive power on the business cycle that began in 2000.

\section{NEW TRENDS IN ECONOMIC INDICATORS}

The period between 1990 and 2003 reveals an interesting phenomenon of unconventional economy that makes it difficult to predict the trends and the cycles precisely. The unconventional nature of the economy during the 1990's was characterized by a rapid growth rate without serious inflationary problem. Similarly, the recovery in 2003 was characterized by its failure to reduce unemployment rate and a failure to stimulate job growth. Except during the period of 1970's through 1989, inflation has not been a serious problem in the United States. However, there were some years when annual GDP growth rate was $4.5 \%$ or higher, even when inflation rate was $7.5 \%$ or higher. The absence of inflation threat in the United States during the high growth period of the 1990's has been credited to the combination of the high-tech productivity, and the successful monetary policy of Alan Greenspan. However, the situation during the years 2001-2002, during which GDP growth rate dropped precipitously in spite of the absence of inflation is at variance with normal economic phenomena. Some blame it on the "unusually rapid productivity growth during the recent recession and the vigorous use of monetary policy over the last few years that brought the federal fund rate to the lowest level that raises the concern that monetary policy would be helpless in the event of economic relapse", (Auerbach, 2003).

The second and third quarters of 2003, when the GDP growth appeared to have turned back up, unemployment rate continued to remain virtually unchanged, indicating that the GDP growth may not be the necessary and sufficient solution for unemployment problem. The 1993-2000 era was marked by a rapid growth in technology, which stimulated an average annual GDP growth rate of about $4.0 \%$, without the danger of inflation usually associated with this rate of GDP growth, and annual unemployment rate of 5.2\%. The GDP growth and unemployment rates do not reveal a pattern which conforms to a clear theoretical relationship during this period. Between 1994 and 1996 when the GDP growth rate fell, unemployment rate also fell, but not in a way that reflected the decline in the GDP growth rate. Also between 1996 and 1998 when the GDP expanded, unemployment rate recorded only a modest decrease. The recession, which commenced during the fourth quarter of 2000 , also brought with it an unemployment rate which again failed to reflect the precipitous decline in the GDP growth rate. This leaves economists wondering whether conventional economic theory is incapable of explaining some macroeconomic trends of the new economy. These trends are explored in this study.

\section{THEORETICAL FOUNDATIONS}

To explain the variations in the maximum potential output of the economy, a production function model is traditionally employed (Evans 2004). The theory asserts that output can be generated through a variously structured combination of labor, capital and technology trend. The Cobb-Douglas production function is one of such models 
frequently used. This study does not deal directly with the production function in the sense of quantity of capital and labor, but the related issues of investment acquisition and the use of the existing pool of labor in the economy.

Two causes of the business cycle are investment and technology development. The recession that began in 2001 has been described as an unusual and unconventional economic phenomenon that was not easy to explain. Some economists are inclined to blame the failure of the GDP growth and unemployment rates to respond to the standard economic stabilization policy since the beginning of 2001, on the Y2K doomsday scare. The period beginning from the summer of 1998 was characterized by the Y2K scare syndrome, which gave rise to a spout of feverish technology related investment to stave off the worst consequences of the technology collapse. The Y2K scare led to enormous financial and technological investment in many industrial sectors, such as transportation network, banking and several others, in their effort to ensure that they were "Y2K" compatible. The surge in Y2K compatible equipment boosted the purchase of high-tech equipment from $\$ 526$ to $\$ 561$ billion, and led to a temporary surge in profits of high-tech firms and their stock prices. By the second quarter of 2000, investment had began to slowdown because the concern about Y2K was no longer a real threat. Rightly or wrongly, we may explain these phenomena as part of the so-called "surplus "or "shortage" theory described by (Evans, 2004).

Okun's Law postulates that underutilized resources contribute to fluctuations in real GDP. In this case, the unutilized resources are the millions of potential workers looking for jobs that they could not find. Resources are under-utilized when aggregate demand falls. Aggregate demand deficiency may be due to inadequate consumer spending or inadequate investment demand. Consumer spending averaged above $2.4 \%$ per annum in the 1970 's, about $2 \%$ in the 1980 's, about $0.6 \%$ in the 1990 's and $0.3 \%$ since 2000 , (U. S. Department of Commerce). To ensure a sustained growth in output, efforts must therefore be made to stabilize consumer and investment spending. According to Okun's Law, unemployment falls (rises) when real GDP grows faster (slower) than potential output. If you know what is happening to real GDP relative to potential output, you know a good ideal of what is happening to the unemployment rate, and vice versa, (DeLong, 2003). An increase or decrease in consumption will result in a parallel increase or decrease in GDP and a corresponding decrease or increase in unemployment rate.

Traditional recovery strategy includes the use of fiscal or monetary expansion or both. However, for these to be effective, the economy must neither be close to full employment, nor be threatened by inflation. Fiscal expansion involves the funding of public projects and entitlement programs, as well as statutory funding release to the states and local to enable them fund their pet projects, such as welfare, public school and poverty projects. Output can be explained with lagged output and fiscal policy. Unfortunately, one may not adequately identify the effect of different components of the fiscal policies, (Auerbach, et al., 2003). The reason for this is timing, expectations, and whether such policy results in more consumption, savings or investment. The problem of timing and uncertain efficacy of fiscal policy could be due, among others to the wrong choice of sectoral and program emphasis. This requires that monetary policy be harmonized with the fiscal policy. The period since year 2000 has seen a series of interest rate reductions in an attempt to encourage private sector initiative in investment and consumer spending and to stimulate GDP and job growth. These objectives have remained largely unrealized.

According to (Auerbach, et al., 2003), the variations in output can be explained as follows:

$\log (\mathrm{y})=\alpha_{0}+\alpha_{1} \log \left(\mathrm{y}_{\mathrm{g}}\left({ }_{-1}\right) / \mathrm{y}_{\mathrm{p}}\right)+\alpha_{2} \log \left(\operatorname{def}\left({ }_{-1}\right) / \mathrm{y}_{\mathrm{p}}\right)+\alpha_{3} \log \left(\mathrm{I}\left({ }_{-1}\right) / \mathrm{y}_{\mathrm{p}}\right)+v$

$\mathrm{Y}_{\mathrm{g}(-1)}$ represents lagged output gap, $\left.\operatorname{def}_{-1}\right)$ represents lagged budget deficit, $\left.\mathrm{I}_{-1}\right)$ represents lagged value of gross investment, and $\mathrm{y}_{\mathrm{p}}$ represents potential output, $v$ represents the white noise error term, considered to be normally and independently distributed with mean zero and standard deviation $\sigma_{y}$. However, this study departs from equation (1) in two respects, firstly our model uses GDP in place of output gap, and government spending in place of budget deficit, because of the author's desire to test the appropriateness of GDP and government spending, assumed to be appropriate proxies for these variables. Secondly, we use vector autoregressive (VAR) method for our structural estimation technique, being a very suitable estimation technique that can control for shocks to endogenous variables. The study stresses the comparative impact of monetary and fiscal policies on GDP and job growth. 


\section{THE VAR MODEL}

This section presents the VAR models used to explain the relationship between GDP growth rate, unemployment rate and job growth, mainly in manufacturing and the services sector.

$\Lambda \mathrm{X}_{\mathrm{t}}=\alpha_{0}+\Sigma \alpha_{\mathrm{i}} \Lambda \mathrm{X}_{\mathrm{t}-\mathrm{j}}+\Sigma \beta_{\mathrm{i}} \Lambda \mathrm{Z}_{\mathrm{t}-\mathrm{j}}+\varepsilon_{\mathrm{t}}$

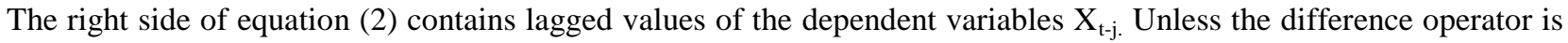
applied to the error term, this might lead to a loss of information. The error correction procedure is often used to prevent this loss of information. The maximum eigenvalue tests allow us to test the hypothesis that there are $r$ cointegrating vectors against an alternative hypothesis that there are $r+1$ vectors. Although the VAR model does not require a rigorous theoretical formulation, we are presenting, not only a specification between a set of endogenous and exogenous variables per say, but also a model that contains some theoretical justifications. The VAR method requires that we first conduct a number of tests on the sample. These are respectively, the unit root and the co-integration tests. For the unit root tests, we conducted the augmented Dickey-Fuller (ADF), and the Philips-Perron (PP) tests.

ADF test: $\Delta \mathrm{y}_{\mathrm{t}}=\mu_{0}+\gamma_{1} \mathrm{y}_{\mathrm{t}-1}+\Sigma \delta_{\mathrm{k}} \Delta \mathrm{y}_{\mathrm{t}-\mathrm{k}}+\varepsilon_{\mathrm{t}}$

PP test: $\quad y_{t}=\alpha_{0}+\alpha_{1} y_{t-1}+v_{t}$

where $y_{t}$ represents, respectively GDP, overall job growth, job growth in the manufacturing and services sectors, and unemployment rate, and $\Delta$ represents the first difference operator. The null hypothesis in the unit root test requires that $\gamma_{1}=0$ in the ADF test, and $\alpha_{1}=1$ in the PP test. For the co-integration test, we performed the Johansen's test. If there is a linear combination of two or more series, such series are said to be co-integrated and such co-integration results in a reduced rank among the series. Engel and Granger (1987) has shown that if a linear combination of two or more non-stationary series exists, such linear combinations might by stationary. For a VAR model of the order $p$, a Johansen's co-integration test uses the following model:

$\mathrm{y}_{\mathrm{t}}=\mathrm{A}_{1} \mathrm{y}_{\mathrm{t}-1}+\ldots \ldots+\mathrm{A}_{\mathrm{p}} \mathrm{y}_{\mathrm{t}-\mathrm{p}}+\mathrm{Bx}_{\mathrm{t}}+\varepsilon_{\mathrm{t}}$

where $\mathrm{y}_{\mathrm{t}}$ represent a k-vector of non-stationary $\mathrm{I}(1)$ variable, $\mathrm{x}_{\mathrm{t}}$ represents a vector of deterministic variables and $\varepsilon_{\mathrm{t}}$ is a vector of innovations. The Johansen's tests permit us to obtain impulse responses and the error decomposition of the dependent variables in the VAR models, (Engel \& Granger, 1987; Johansen \& Juselius, 1990; Eun \& Jeong, 1999).

Following is the brief description and the structural relationship of the instrumental variables in the model tested. The dependent variables are GDP growth, overall job growth, manufacturing job growth, and job growth in the services sector. Among the independent variables are lagged values of these dependent variables. Others are money supply and government spending as a ratio of GDP. No detailed discussion is given here because these are traditional instruments to bring about expansion, job growth and inflation control. The desired results are achieved through their effects on consumer spending and investment spending. Consumer spending (CS) and investment as a ratio of GDP (i/y), although endogenous variables, are included among independent variables with the hope that the reduced form procedure in the VAR model will control for the effect of the cointegration. The remaining independent variables are consumer confidence and productivity in manufacturing. Although productivity appears to have indisputable theoretical significance in a model such as this, consumer confidence does not. Consumer confidence is widely believed to affect consumer and investors' spending behavior, but there appears to be no rigorous theoretical foundation for this.

\section{EMPIRICAL RESULTS OF THE VAR MODELS}

The results of the unit root, and the Johansen's co-integration tests are presented in Table 1. The results of the error correction estimates of the VAR models, and the error decomposition tests are given in Table 2 and Table 3, respectively. While Table 1 provides us with the results of the tests performed on the database, to ensure that the variables possess the properties that can yield unbiased parameters, Table 2 and Table 3 contain the empirical results 
of the hypotheses tested. To clarify, these hypotheses are restated here for easy reference. The first is that the factors which determine the GDP growth are different from those that determine job growth. For this reason, policies which are effective in stimulating GDP growth are often incapable of producing significant job growth. As a result of this, significant GDP growth is not always followed by a declining unemployment rate. The link between GDP growth rate and unemployment rate is job growth. That job growth is mostly in manufacturing. We believe that emphasizing manufacturing job growth by whatever means, including the measures suggested below, will be more effective in bringing about job growth and unemployment situations that will be in line with the GDP growth rate.

The second hypothesis is that the conventional methods of bringing about GDP expansion and job growth have lost their predictive power on the business cycle of the $21^{\text {st }}$ century. This study has shown that this is not the case. On the contrary we found that the over-reliance on fiscal stimulation can be ineffective, especially in the economic environment where the monetary instrument cannot stimulate the desired investment spending, due to the perverse low investors' confidence. The empirical results show that, except in the case of job growth in the services, and the unemployment rate equations, the fiscal policy variable is not statistically significant. The monetary policy variable is however, statistically significant. The variance decomposition shows that when M1 is included, and when it is excluded from the VAR models, GDP accounts for a higher proportion of the variances in job growth (manufacturing), but much less proportion of the variances in the services job growth when M1 is excluded from the VAR model.

The empirical results presented in Tables 2 and 3 are complementary and we intend that they be read together. Table 2 shows the structural relationship between the various dependent and independent variables, and Table 3 shows the proportion of the variances in the dependent variable explained by a shock to the independent variables as indicated. The dependent variables are GDP, overall job growth, manufacturing and services job growth, and unemployment. The independent variables are, in particular fiscal and monetary policy variables, corporate profit, productivity (manufacturing), consumer spending, ratio of gross private investment to GDP, consumer confidence index, and lagged values of the respective dependent variables. To test the comparative impact of the monetary and fiscal policy variables, the VAR models are estimated to include M1, and when M1 is excluded. The exclusion of M1 tests the effectiveness of independent fiscal injection into the economy with little regard to any existing monetary policy, as has been the case since 2001, following the series of tax cuts and massive government spending especially on Homeland Security-related programs.

This empirical evidence addresses two theoretical facts. (i) In a simultaneous injection of fiscal and monetary policy innovations into the economy, monetary innovation tends to exert a dominant impact on the economy because of its immediate expansionary effect on domestic investment. (ii) Although the manufacturing sector has been declining since 1980's, due among others, to the so-called "outsourcing" phenomenon, which encourages American companies to relocate their manufacturing plants overseas, the link between the GDP growth and the unemployment rate is job growth, especially in the manufacturing. It is not quite clear why the services sector, with its $31 \%$ share of nonagricultural payroll, and about $38 \%$ share as source of personal income, is not quite able to create significant number of jobs to allow job growth to keep up with the GDP growth. Corporate profit and gross private domestic investment variables which are statistically significant in the manufacturing job growth equation are not statistically significant in the services job growth equation. These are indications that private investment and corporate profit play important role in stimulating job growth in the manufacturing, more than they play in the services sector. The pressure to maintain this level of corporate profit is behind the manufacturing industry's motivation to move plants overseas, especially to countries where low wage employees can be hired. We tested the effect of trade deficit on GDP growth rate, as well as on the overall and manufacturing job growth in the VAR model, and found that trade deficit significantly reduces the GDP growth rate, as well as the overall and manufacturing job growth.

One of the ways by which we can prevent the relocation of manufacturing plants overseas is to enact an appropriate tax legislation providing greater incentives to encourage more domestic investments, and discourage relocation of manufacturing plants overseas. Businesses could be allowed to take tax write-offs for proven cases of authentic jobs created on minimum and above minimum wage rate. Alternatively, corporations seen to have abnormally high propensity to relocate their plants overseas, may be taxed at a relatively higher rate than their domestic counterparts. The effectiveness of a fiscal policy depends on whether it results in relatively more investment 
spending, consumption or saving. To strengthen the effectiveness of the proposed tax policy, appropriate steps should be taken to ensure the highest level of investors' confidence in the economy. Such steps include policy to reduce trade and budget deficits and guarantee the stability of the social security account.

The VAR models reveal the overwhelming role played by M1, the ratio of gross private domestic investment to GDP, and consumer confidence index on GDP, overall job growth, and manufacturing and services job growth, as well as on unemployment. They also show that productivity increase leads to GDP growth slowdown and manufacturing job loss. The data, however show that, except for selected years between 1970 through 1999, productivity averaged at least 3.0, and except 1970, 1974-75, and 1990 average GDP growth rate was also at least $3.0 \%$ per annum. During the period 2000 through 2002, average productivity growth was 3.9 while average GDP growth was $2.1 \%$ per annum. Except for selected years, consumer confidence index has been less than 100\%. In 1999, the index shot up to 139, and dropped to $106.6 \%$ in 2001 and 96.6 in 2002. Given these statistics, high productivity cannot be interpreted to be contractionary, because it is not. If consumer and investors' confidence are satisfactorily high, potential workers who cannot be hired in sectors where they do not possess the desired skills, could be employed in other sectors, where there is adequate investment to stimulate more output and employment growth. The models further demonstrate that when there is a simultaneous injection of monetary and fiscal expansion, the overall effect on job growth and unemployment reduction will be dominated by the monetary expansion because of its prompt effect on interest rate reduction and investment spending. It is not quite clear why similar results are not evident in the services sector. Robust corporate profits also tend to stimulate faster GDP growth, and job growth in the manufacturing, but not in the services sectors, although employee lay-offs are more often used in the manufacturing sectors as a cushion to prop-up corporate profits to prevent them from declining.

Table 3 shows the percentage contributions of the variances accounted for by the GDP in overall job growth, and job growth in the manufacturing, services, as well as unemployment, when government spending and money supply are considered together, and when money supply is excluded. Although the VAR models show that not more than two lagged periods in the dependent variables can be included in the models, the horizon in the variance decomposition has been extended to ten years. The variance decomposition analysis shows that the GDP accounts for a higher proportion of the variances in overall job growth, manufacturing, and services job growth, especially when M1 is included in the VAR model.

\section{CONCLUSIONS}

The study shows that tax reduction and increased government spending, which are traditionally used to bring about economic expansion, are not always capable of bringing about a corresponding decrease in the unemployment rate. It is sometimes possible to achieve GDP growth, if such policies are supported with appropriate monetary expansion, but it may nevertheless not come with a corresponding amount of job growth.

Although manufacturing has been declining since mid 1980's, due to corporate outsourcing, which involves relocating of manufacturing plants overseas, that sector is more capable of bringing about the amount of job growth that may keep pace with the GDP growth rate. Strong job growth requires robust corporate profits and significant investment. Although the Services sector has been expanding since the 1980's job growth has not always kept pace with the GDP growth rate because less than adequate corporate profits have been reported in those sectors. However, robust corporate profits and active investment spending which have been able to stimulate job growth in the manufacturing sectors have not produced such results in the services sectors.

Monetary policy instrument is more effective in stimulating GDP expansion and comparable job growth, and hence in reducing unemployment rate, than fiscal innovation. One of the reasons for this is that fiscal innovations, which are not perceived by investors to be pro-investment, often result in low investors' confidence. Except where there is a pervasive low investors' confidence, monetary expansion generally results in increased investment due to low interest rate. Significant job creation generally occurs in the sectors in which significant investments take place, resulting in rapid GDP growth. 
The failure to realize the anticipated job growth, following the enormous fiscal injection and tax reduction initiatives since 2001 is mostly due to three reasons: (1) The pervasive low investors' confidence had drastically reduced the investors' propensity to invest to the extent that little or no investment could take place, even if interest rate which had fallen to its lowest level could be allowed to fall further. (2) Many industrial sectors, still saturated with excess technological investment acquired in 1998-99 in their attempt to remain Y2K compatible, were trying to make effective use of their existing investment and hence had no justification for further investment spending, and this constrained their ability to expand production and create jobs. (3) The pressure to prevent corporate profits from falling had increased the motivation to move industrial plants overseas, especially to low wage countries.

Table 1: (A) Unit Root Test

Variable

Unemployment

Productivity Manufacturing

M1

Overall Job Growth

Manufacturing Job Growth

Services Job Growth

Government Spending

Consumer Spending

Consumer Confidence Index

Corporate Profit

Inflation Rate

Private Domestic Investment

GDP

Unemployment

Overall Job Growth

Manufacturing Job Growth

Job Growth (Services)

\author{
Augmented Dickey-Fuller \\ (ADF) Test
}

Test

Result

$-4.28 *$

$-2.64 *$

$-4.30 *$

$-3.66$

$-3.65 *$

$-4.28 *$

$-4.27 *$

$-3.66 *$

$-4.39 *$

$-4.28 *$

$-3.77 *$

$-3.66 *$

Critical
Value

$-3.04$

$-1.36$

$-1.97$

$-2.73$

$-1.33$

$-3.59$

$-2.95$

$-1.63$

$-3.02$

$-2.15$

$-3.10$

$-2.56$
Philips-Perron
(PP) Test

$\begin{array}{ll}\begin{array}{l}\text { Test } \\ \text { Result }\end{array} & \begin{array}{l}\text { Critical } \\ \text { Value }\end{array} \\ -3.65 & -2.20 \\ -2.63 & -1.90 \\ -3.66 & -1.82 \\ -4.27 & -1.94 \\ -3.65 & -1.14 \\ -3.66 & -1.97 \\ -4.27 & 2.91 \\ -4.28 & -3.58 \\ -3.65 & -2.48 \\ -4.27 & -1.97 \\ -4.30 & -2.06 \\ -4.27 & -1.71\end{array}$

Table 1: (B) Test For Co-Integration (Trace Test)

$\begin{array}{llll}\begin{array}{lll}\text { Test } \\ \text { Statistics }\end{array} & \begin{array}{l}\text { Critical } \\ \text { Value }\end{array} & \begin{array}{l}\text { Test } \\ \text { Statistics }\end{array} & \begin{array}{l}\text { Critical } \\ \text { Value }\end{array} \\ 16.88^{* *} & 15.41 & 0.11 & 6.65 \\ 30.37 * & 20.04 & 0.0005 & 6.65 \\ 30.37 * & 20.04 & 0.0005 & 6.26 \\ 25.97^{*} & 20.04 & 0.10 & 6.65 \\ 35.55^{* *} & 20.04 & 4.81 & 3.76\end{array}$

Table 1: (C) Test For Co-Integration (Maximum Eigenvalue Test)

$\begin{array}{lllll} & \begin{array}{l}\text { Test } \\ \text { Statistics }\end{array} & \begin{array}{l}\text { Critical } \\ \text { Value }\end{array} & \begin{array}{l}\text { Test } \\ \text { Statistics }\end{array} & \begin{array}{l}\text { Critical } \\ \text { Value }\end{array} \\ & & & & \\ \text { GDP } & 16.77^{* *} & 14.07 & 0.11 & 3.76 \\ \text { Unemployment } & 30.36^{*} & 18.63 & 0.0005 & 6.65 \\ \text { Overall Job Growth } & 30.36^{* *} & 18.63 & 0.0005 & 3.76 \\ \text { Manufacturing Job Growth } & 25.99^{*} & 20.04 & 0.10 & 6.65 \\ \text { Job Growth (Services) } & 30.18^{*} & 18.63 & 4.81^{* *} & 3.76\end{array}$


Table 2: Estimated Results Of The VAR Models

Independent Variables

Dependent Variables

\begin{tabular}{|c|c|c|c|c|c|c|c|c|}
\hline & GDP & JG & GDP & JGM & GDP & JGS & GDP & $\mathrm{U}$ \\
\hline \multicolumn{9}{|c|}{ Co-integrating equation } \\
\hline $\log (\operatorname{GDP}(-1))$ & 1.00 & - & 1.00 & - & 1.00 & - & 1.00 & - \\
\hline $\log (\mathrm{JG}(-1))$ & $\begin{array}{l}.59 \\
(1.86)\end{array}$ & - & - & - & - & - & - & - \\
\hline $\log (\operatorname{JGM}(-1))$ & - & $\begin{array}{l}-.381 \\
(3.671)^{*}\end{array}$ & - & - & - & - & - & - \\
\hline $\log (\operatorname{JGS}(-1))$ & - & - & - & - & $\begin{array}{l}0.864 \\
(3.174)^{*}\end{array}$ & - & - & - \\
\hline $\log (\mathrm{U}(-1))$ & - & - & - & - & - & - & $\begin{array}{l}-0.057 \\
(1.531)\end{array}$ & - \\
\hline Constant & -15.20 & - & -4.672 & - & -18.126 & - & -8.287 & \\
\hline \multicolumn{9}{|c|}{ Error Correction } \\
\hline CointEq1 & $\begin{array}{l}-0.574 \\
(3.78)^{*}\end{array}$ & $\begin{array}{l}-0.336 \\
(2.854)^{* *}\end{array}$ & $\begin{array}{l}-0.913 \\
(4.301)^{*}\end{array}$ & $\begin{array}{l}-0.272 \\
(0.549)\end{array}$ & $\begin{array}{l}-0.517 \\
(4.011)^{*}\end{array}$ & $\begin{array}{l}-0.306 \\
(4.241)^{*}\end{array}$ & $\begin{array}{l}-0.581 \\
(3.452)^{*}\end{array}$ & $\begin{array}{l}1.039 \\
(0.990)\end{array}$ \\
\hline $\log (\operatorname{GDP}(-1))$ & $\begin{array}{l}-0.039 \\
(0.198)\end{array}$ & $\begin{array}{l}0.254 \\
(1.641)\end{array}$ & $\begin{array}{l}0.053 \\
(0.291)\end{array}$ & $\begin{array}{l}0.558 \\
(1.298)\end{array}$ & $\begin{array}{l}-0.218 \\
(1.008)\end{array}$ & $\begin{array}{l}0.307 \\
(2.531)^{*}\end{array}$ & $\begin{array}{l}-0.038 \\
(0.190)\end{array}$ & $\begin{array}{l}-1.666 \\
(1.341)\end{array}$ \\
\hline $\log (\operatorname{GDP}(-2))$ & $\begin{array}{l}-.0 .159 \\
(0.866)\end{array}$ & $\begin{array}{l}-0.120 \\
(0.842)\end{array}$ & $\begin{array}{l}-0.118 \\
(0.0 .649\end{array}$ & $\begin{array}{l}0.019 \\
(0.045)\end{array}$ & $\begin{array}{l}-0.161 \\
(0.944)\end{array}$ & $\begin{array}{l}0.053 \\
(0.557)\end{array}$ & $\begin{array}{l}-0.165 \\
(0.880)\end{array}$ & $\begin{array}{l}0.261 \\
(0.223)\end{array}$ \\
\hline $\log (J G(-1))$ & $\begin{array}{l}-0.062 \\
(0.265)\end{array}$ & $\begin{array}{l}-0.027 \\
(0.146)\end{array}$ & - & - & - & - & - & - \\
\hline $\log (J G(-2))$ & $\begin{array}{l}0.290 \\
(1.568)\end{array}$ & $\begin{array}{l}-0.006 \\
(0.040)\end{array}$ & - & - & - & - & - & - \\
\hline $\log (\operatorname{JGM}(-1))$ & - & - & $\begin{array}{l}-.234 \\
(2.596) * *\end{array}$ & $\begin{array}{l}-0.536 \\
(2.544)^{* *}\end{array}$ & - & - & - & - \\
\hline $\log (\operatorname{JGM}(-2))$ & - & - & $\begin{array}{l}-0.096 \\
(1.138)\end{array}$ & $\begin{array}{l}-0.397 \\
(2.020)^{* *}\end{array}$ & - & - & - & - \\
\hline $\log (\mathrm{JGS}(-1))$ & - & - & - & - & $\begin{array}{l}0.155 \\
(0.428)\end{array}$ & $\begin{array}{l}-0.049 \\
(-0.241)\end{array}$ & - & - \\
\hline $\log (\operatorname{JGS}(-2))$ & - & - & - & - & $\begin{array}{l}0.275 \\
(1.172)\end{array}$ & $\begin{array}{l}0.026 \\
(0.201)\end{array}$ & - & - \\
\hline Constant & $\begin{array}{l}-4.575 \\
(3.272)^{*}\end{array}$ & $\begin{array}{l}-3.023 \\
(2.788)^{* *}\end{array}$ & $\begin{array}{l}-6.676 \\
(3.828)^{*}\end{array}$ & $\begin{array}{l}-2.029 \\
(0.498)\end{array}$ & $\begin{array}{l}-4.578 \\
(3.449)^{*}\end{array}$ & $\begin{array}{l}-3.284 \\
(4.417)^{*}\end{array}$ & $\begin{array}{l}-3.995 \\
(2.915)^{*}\end{array}$ & $\begin{array}{l}9.106 \\
(1.066)\end{array}$ \\
\hline $\log (\mathrm{M} 1)$ & $\begin{array}{l}-0.039 \\
(1.050)\end{array}$ & $\begin{array}{l}0.090 \\
(3.128)^{*}\end{array}$ & $\begin{array}{l}-0.071 \\
(3.790)^{*}\end{array}$ & $\begin{array}{l}0.284 \\
(3.790)^{*}\end{array}$ & $\begin{array}{l}-0.072 \\
(1.730)\end{array}$ & $\begin{array}{l}0.074 \\
(3.145)^{*}\end{array}$ & $\begin{array}{l}-0.018 \\
(0.450)\end{array}$ & $\begin{array}{l}-1.424 \\
(5.810)^{*}\end{array}$ \\
\hline
\end{tabular}




\begin{tabular}{|c|c|c|c|c|c|c|c|c|}
\hline Def/y & $\begin{array}{l}0.133 \\
(1.194)\end{array}$ & $\begin{array}{l}-0.016 \\
(0.180)\end{array}$ & $\begin{array}{l}-0.150 \\
(1.639)\end{array}$ & $\begin{array}{l}-0.289 \\
(1.346)\end{array}$ & $\begin{array}{l}0.219 \\
(1.751)\end{array}$ & $\begin{array}{l}0.166 \\
(2.373) * *\end{array}$ & $\begin{array}{l}0.072 \\
(0.627)\end{array}$ & $\begin{array}{l}1.811 \\
(2.514)^{* *}\end{array}$ \\
\hline $\log (\mathrm{CP})$ & $\begin{array}{l}0.052 \\
(2.468)^{* *}\end{array}$ & $\begin{array}{l}0.021 \\
(1.296)\end{array}$ & $\begin{array}{l}0.054 \\
(2.606) * *\end{array}$ & $\begin{array}{l}0.116 \\
(2.387)^{* *}\end{array}$ & $\begin{array}{l}0.075 \\
(3.392)^{*}\end{array}$ & $\begin{array}{l}0.001 \\
(0.084)\end{array}$ & $\begin{array}{l}0.039 \\
(1.698)\end{array}$ & $\begin{array}{l}-0.061 \\
(0.428)\end{array}$ \\
\hline Log(PRMAN) & $\begin{array}{l}-.005 \\
(2.187)^{* *}\end{array}$ & $\begin{array}{l}-0.001 \\
(0.645)\end{array}$ & $\begin{array}{l}-.001 \\
(0.599)\end{array}$ & $\begin{array}{l}-0.008 \\
(1.322)\end{array}$ & $\begin{array}{l}-0.005 \\
(2.430)^{* *}\end{array}$ & $\begin{array}{l}0.0005 \\
(0.399)\end{array}$ & $\begin{array}{l}-0.005 \\
(1.998)^{* *}\end{array}$ & $\begin{array}{l}0.014 \\
(0.913)\end{array}$ \\
\hline $\log (\mathrm{CS})$ & $\begin{array}{l}0.603 \\
(3.127)^{*}\end{array}$ & $\begin{array}{l}0.290 \\
(1.942) * * *\end{array}$ & $\begin{array}{l}0.770 \\
(3.682)^{*}\end{array}$ & $\begin{array}{l}-.059 \\
(0.121)\end{array}$ & $\begin{array}{l}0.610 \\
(3.392)^{*}\end{array}$ & $\begin{array}{l}0.330 \\
(3.277)^{*}\end{array}$ & $\begin{array}{l}0.517 \\
(2.789)^{* *}\end{array}$ & $\begin{array}{l}0.060 \\
(0.052)\end{array}$ \\
\hline $\log (\mathrm{I} / \mathrm{Y})$ & $\begin{array}{l}0.182 \\
(1.751)^{* * * *}\end{array}$ & $\begin{array}{l}0.080 \\
(2.222)^{* *}\end{array}$ & $\begin{array}{l}0.115 \\
(2.719)^{* *}\end{array}$ & $\begin{array}{l}0.191 \\
(1.932)^{*}\end{array}$ & $\begin{array}{c}0.046 \\
(0.919)\end{array}$ & $\begin{array}{l}-0.0009 \\
(0.033)\end{array}$ & $\begin{array}{l}0.082 \\
(1.605)\end{array}$ & $\begin{array}{l}-1.233 \\
(3.888)^{*}\end{array}$ \\
\hline $\log (\mathrm{CCI})$ & $\begin{array}{l}-0.018 \\
(0.966)\end{array}$ & $\begin{array}{l}0.030 \\
(2.092)^{* *}\end{array}$ & $\begin{array}{l}-0.002 \\
(0.182)\end{array}$ & $\begin{array}{l}0.059 \\
(1.854)^{* * *}\end{array}$ & $\begin{array}{l}-0.026 \\
(1.116)\end{array}$ & $\begin{array}{l}0.032 \\
(2.492)^{* *}\end{array}$ & $\begin{array}{l}-0.007 \\
(0.400)\end{array}$ & $\begin{array}{l}-0.461 \\
(3.862)^{*}\end{array}$ \\
\hline R-Squared & 0.945 & 0.927 & 0.954 & 0.845 & 0.943 & 0.930 & 0.938 & 0.922 \\
\hline F-Statistic & 21.345 & 15.833 & 23.976 & 6.831 & 20.878 & 16.555 & 18.873 & 14.900 \\
\hline Akaika AIC & -6.402 & -6.911 & -6.512 & -4.816 & -6.381 & -7.541 & -6.286 & -2.626 \\
\hline Log Likelihood & 106.633 & 109.754 & 104.174 & 80.430 & 102.340 & 118.571 & 101.010 & 49.767 \\
\hline
\end{tabular}

*Statistically Significant at $1 \%$ level; **Statistically Significant at5\% level

List and Description of Variables Used

$\begin{array}{lll}\mathrm{y} & = & \text { gross domestic product } \\ \mathrm{prman} & = & \text { productivity (manufacturing) } \\ \mathrm{def} / \mathrm{y} & = & \text { government spending as ratio of GDP } \\ \mathrm{i} / \mathrm{y} & = & \text { gross private domestic investment as share of GDP } \\ \mathrm{cs} & = & \text { private consumption spending } \\ \mathrm{cci} & = & \text { consumer confidence index } \\ \mathrm{jg} & = & \text { overall job growth } \\ \mathrm{jgm} & = & \text { manufacturing job growth } \\ \mathrm{jgs} & = & \text { job growth (services) } \\ \mathrm{u} & = & \text { unemployment rate } \\ \mathrm{cp} & = & \text { corporate profit }\end{array}$

Table 3: Variance Decomposition - Proportion Of Variances Explained By Shock To Independent Variables On The Dependent Variables

Shock to $\log (G D P)$ When M1 is included in the VAR Model

$\begin{array}{lclc}\text { Period } & \text { Standard Error } & \text { GDP } & \text { Overall Job Growth } \\ 1 & 0.008 & 100.00 & 0.00 \\ 2 & 0.009 & 92.67 & 7.32 \\ 3 & 0.009 & 92.14 & 7.86 \\ 4 & 0.009 & 89.51 & 10.48 \\ 5 & 0.010 & 83.21 & 16.79 \\ 6 & 0.010 & 80.02 & 19.98 \\ 7 & 0.010 & 76.85 & 23.15 \\ 8 & 0.011 & 73.45 & 26.55 \\ 9 & 0.011 & 70.89 & 29.11 \\ 10 & 0.011 & 68.43 & 31.57\end{array}$


Shock to $\log (G D P)$ on JGS When M1 is included in the VAR Model

$\begin{array}{lcll}\text { Period } & \text { Standard Error } & \text { GDP } & \text { JGS } \\ 1 & 0.008 & 100.00 & 0.00 \\ 2 & 0.009 & 97.59 & 2.41 \\ 3 & 0.009 & 96.95 & 3.05 \\ 4 & 0.009 & 92.99 & 7.01 \\ 5 & 0.010 & 89.10 & 10.89 \\ 6 & 0.010 & 86.55 & 13.45 \\ 7 & 0.010 & 84.16 & 15.84 \\ 8 & 0.011 & 82.10 & 17.90 \\ 9 & 0.011 & 80.37 & 19.62 \\ 10 & 0.011 & 78.77 & 21.23\end{array}$

Shock to $\log (G D P)$ on JGM When M1 is included in the VAR Model

$\begin{array}{lcll}\text { Period } & \text { Standard Error } & \text { GDP } & \text { JGM } \\ 1 & 0.008 & 100.00 & 0.00 \\ 2 & 0.008 & 96.42 & 3.58 \\ 3 & 0.009 & 85.55 & 14.45 \\ 4 & 0.010 & 77.95 & 22.05 \\ 5 & 0.011 & 73.16 & 26.84 \\ 6 & 0.012 & 67.84 & 32.15 \\ 7 & 0.013 & 63.55 & 36.45 \\ 8 & 0.013 & 60.53 & 39.46 \\ 9 & 0.014 & 57.79 & 42.21 \\ 10 & 0.015 & 55.45 & 44.55\end{array}$

Shock to $\log (G D P)$ on $U$ When M1 is included in VAR Model

$\begin{array}{lcll}\text { Period } & \text { Standard Error } & \text { GDP } & \mathrm{U} \\ 1 & 0.009 & 100.00 & 0.00 \\ 2 & 0.009 & 96.19 & 3.806 \\ 3 & 0.009 & 96.148 & 3.852 \\ 4 & 0.009 & 95.254 & 4.746 \\ 5 & 0.010 & 91.249 & 8.751 \\ 6 & 0.010 & 90.010 & 9.990 \\ 7 & 0.010 & 88.735 & 11.265 \\ 8 & 0.010 & 86.329 & 13.671 \\ 9 & 0.010 & 84.712 & 15.287 \\ 10 & 0.010 & 83.271 & 16.729\end{array}$

Shock to Log(GDP) on JG When M1 is Excluded from VAR Model

$\begin{array}{lcll}\text { Period } & \text { Standard Error } & \text { DP } & \text { JG } \\ 1 & 0.009 & 100.00 & 0.00 \\ 2 & 0.012 & 84.99 & 15.01 \\ 3 & 0.013 & 81.68 & 18.32 \\ 4 & 0.015 & 79.44 & 20.56 \\ 5 & 0.017 & 75.15 & 24.84 \\ 6 & 0.019 & 73.51 & 26.49 \\ 7 & 0.020 & 72.33 & 27.66 \\ 8 & 0.022 & 71.28 & 28.72 \\ 9 & 0.023 & 70.73 & 29.27 \\ 10 & 0.024 & 70.25 & 29.75\end{array}$


Shock to $\log (G D P)$ on JGS When M1 is Excluded from VAR Model

$\begin{array}{lcll}\text { Period } & \text { Standard Error } & \text { GDP } & \text { JGS } \\ 1 & 0.010 & 100.00 & 0.00 \\ 2 & 0.012 & 91.18 & 8.81 \\ 3 & 0.014 & 89.17 & 10.83 \\ 4 & 0.016 & 87.81 & 12.18 \\ 5 & 0.018 & 86.60 & 13.39 \\ 6 & 0.020 & 86.19 & 13.81 \\ 7 & 0.022 & 85.99 & 14.01 \\ 8 & 0.023 & 85.88 & 14.12 \\ 9 & 0.025 & 85.82 & 14.17 \\ 10 & 0.026 & 85.76 & 14.23\end{array}$

Shock to Log(GDP) on JGM When M1 is Excluded from VAR Model

$\begin{array}{lcll}\text { Period } & \text { Standard Error } & \text { GDP } & \text { JGM } \\ 1 & 0.009 & 100.00 & 0.00 \\ 2 & 0.010 & 93.28 & 6.72 \\ 3 & 0.011 & 84.70 & 15.30 \\ 4 & 0.013 & 82.83 & 17.17 \\ 5 & 0.014 & 80.80 & 19.19 \\ 6 & 0.015 & 78.76 & 21.24 \\ 7 & 0.016 & 77.73 & 22.26 \\ 8 & 0.017 & 76.81 & 23.19 \\ 9 & 0.018 & 75.93 & 24.07 \\ 10 & 0.019 & 75.33 & 24.67\end{array}$

Shock to Log(JGS) on U When M1 is included in the VAR Model

$\begin{array}{lcll}\text { Period } & \text { Standard Error } & \text { JGS } & \mathrm{U} \\ 1 & 0.005 & 68.76 & 31.23 \\ 2 & 0.006 & 62.62 & 37.38 \\ 3 & 0.007 & 55.98 & 44.02 \\ 4 & 0.007 & 52.70 & 47.30 \\ 5 & 0.008 & 52.03 & 47.97 \\ 6 & 0.008 & 51.28 & 48.71 \\ 7 & 0.008 & 49.44 & 50.56 \\ 8 & 0.009 & 47.31 & 52.69 \\ 9 & 0.009 & 45.47 & 54.53 \\ 10 & 0.009 & 43.84 & 56.16\end{array}$

Shock to Log(JGM) on U When M1 is included in the VAR Model

$\begin{array}{lccc}\text { Period } & \text { Standard Error } & \text { JGM } & \mathrm{U} \\ 1 & 0.019 & 87.48 & 12.52 \\ 2 & 0.023 & 88.83 & 11.19 \\ 3 & 0.025 & 86.64 & 13.36 \\ 4 & 0.029 & 85.03 & 14.96 \\ 5 & 0.031 & 85.86 & 14.13 \\ 6 & 0.034 & 86.01 & 13.99 \\ 7 & 0.036 & 85.33 & 14.67 \\ 8 & 0.038 & 85.20 & 14.80 \\ 9 & 0.040 & 85.34 & 14.65 \\ 10 & 0.042 & 85.29 & 14.71\end{array}$


Shock to Log(JG) on U When MI is included in the VAR Model

$\begin{array}{lrll}\text { Period } & \text { Standard Error } & \text { JG } & \text { U } \\ 1 & 0.005 & 35.68 & 64.31 \\ 2 & 0.005 & 34.05 & 65.94 \\ 3 & 0.006 & 37.86 & 62.13 \\ 4 & 0.008 & 49.03 & 50.97 \\ 5 & 0.009 & 57.13 & 42.87 \\ 6 & 0.010 & 58.76 & 41.24 \\ 7 & 0.011 & 56.50 & 43.50 \\ 8 & 0.011 & 54.36 & 45.64 \\ 9 & 0.011 & 52.78 & 47.22 \\ 10 & 0.012 & 51.73 & 48.20\end{array}$

Shock to Log(JGS) on U When M1 is excluded from the VAR Model

$\begin{array}{lcll}\text { Period } & \text { Standard Error } & \text { JGS } & \mathrm{U} \\ 1 & 0.005 & 70.40 & 29.60 \\ 2 & 0.006 & 61.83 & 38.17 \\ 3 & 0.007 & 51.41 & 48.59 \\ 4 & 0.008 & 45.81 & 54.19 \\ 5 & 0.009 & 46.10 & 53.89 \\ 6 & 0.010 & 47.91 & 52.08 \\ 7 & 0.011 & 48.62 & 51.37 \\ 8 & 0.012 & 48.61 & 51.39 \\ 9 & 0.012 & 48.49 & 51.51 \\ 10 & 0.013 & 48.19 & 51.50\end{array}$

Shock to $\log (J G)$ on $U$ When M1 is excluded from the VAR Model

$\begin{array}{lcll}\text { Period } & \text { Standard Error } & \text { JG } & \text { U } \\ 1 & 0.005 & 44.43 & 55.57 \\ 2 & 0.005 & 40.24 & 59.75 \\ 3 & 0.006 & 41.86 & 58.14 \\ 4 & 0.011 & 46.66 & 53.34 \\ 5 & 0.017 & 55.32 & 44.68 \\ 6 & 0.022 & 59.05 & 40.95 \\ 7 & 0.027 & 59.89 & 40.11 \\ 8 & 0.031 & 60.71 & 39.29 \\ 9 & 0.034 & 61.20 & 38.80 \\ 10 & 0.038 & 61.35 & 38.65\end{array}$

Shock to Log(JGM) on U When M1 is excluded from VAR Model

$\begin{array}{lcll}\text { Period } & \text { Standard Error } & \text { JGM } & \mathrm{U} \\ 1 & 0.022 & 100.00 & 0.00 \\ 2 & 0.026 & 96.49 & 3.51 \\ 3 & 0.026 & 96.31 & 3.69 \\ 4 & 0.027 & 92.50 & 7.50 \\ 5 & 0.028 & 92.18 & 7.82 \\ 6 & 0.028 & 92.37 & 7.63 \\ 7 & 0.029 & 92.47 & 7.53 \\ 8 & 0.029 & 92.21 & 7.78 \\ 9 & 0.029 & 91.91 & 8.08 \\ & 0.030 & 91.73 & 8.27\end{array}$




\section{ACKNOWLEDGEMENTS}

I acknowledge the contributions of my MBA students for their assistance in data collection, data analysis, and for their contributions in class discussions, which have helped to crystallize my ideas on many of the issues discussed in this paper.

\section{REFERENCES}

1. Auerbach, Alan J. (1999). On the Performance and Use of Government Revenue Forecasts, National Tax Journal, 56(4).

2. William G. Gale and William D. Nordhaus (2003). Fiscal Policy, Past and Present/Comments and Discussion, Brookings Papers on Economic Activity.

3. Broaddus, Jr. J. Alfred. (1996). U. S. Monetary Policy: Looking Back to Find the Future, Federal Reserve Bank of Richmond.

4. Bureau of Labor Statistics, United States Department of Labor (2002). International Comparisons of Manufacturing Productivity and Unit Labor Cost Trends.

5. $\quad$ Evans, Michael K. (2004). Macroeconomics for Managers, Blackwell Publishing.

6. Engel, R. E. and C. W. J. Granger. (1987). Co-integration and Error Correction: Representation, Estimation and Testing, Econometrica, 55, 251-276.

7. Johansen, S. and K. Juselius. (1990). Maximum Likelihood Estimation and Inferences on Co-integrationwith Application on the Demand for Money, Oxford Bulletin on Economics and Statistics, 52, 169-209.

8. Romer, Christina D. and David H. Romer. (1994). What Ends Recessions?, NBER Working Paper, 4765.

9. Shapiro, Matthew D. and Joel Slemrod. (2001). Consumer Response to Tax Rebates, NBER.

10. Souleles, Nicholas S. (1999). The Response of Household Consumption to Income Tax Refunds, The American Economic Review, Volume 89(4).

11. Thorbecke, Willem. (2002). A Dual Mandate for the Federal Reserve: The Pursuit of Price Stability and Full Employment, Eastern Economic Journal (Spring).

12. Thornton, D. L., and S. B. Dallas. (1985). Lag-length Selection and Tests of Granger Causality Between Money and Income, Journal of Money, Credit and Banking, 17(2).

13. Toda, H. Y. and Y. Taku. (1985). Statistical Inference in Vector Autocorrelations With Possible Integrated Process, Journal of Econometrics, 66, 225-250.

14. U. S. Department of Commerce. (Various Years). Economic Report of the President.

15. Weerapana, Akila. (2003). Intermediate Macroeconomics Without IS-LM Model, Journal of Economic Education, 34(3). 


\section{NOTES}

